\title{
Economic feasibility of drip fertigation in okra
}

\section{P.K. JAMREY AND S.S. LAKHAWAT}

Received : 17.07.2017; Revised : 24.08.2017; Accepted : 10.09 .2017

See end of the Paper for authors' affiliation Correspondence to :

\section{P.K. JAMREY}

Rama Krishna Mission Ashrama, Agriculture Training and Demonstration Centre, Brehibeda, NARAYANPUR (C.G.) INDIA

Email : pravinjamrey@gmail. com
- ABSTRACT : Field investigation were carried out at Collage of Technology and Engineering, Udaipur, during Kharif season (July, 2012-November, 2012) to evaluate the economic feasibility of drip fertigation system in okra (Mahyco Bhindi No. 64). The results revealed that drip fertigation recorded significantly higher yield of okra crop. The economic analysis shows that the net income obtained under 75 per cent RDF through fertigation in equal splits at 5 days interval was higher than that of furrow and drip irrigation system. Furrow and drip irrigation registered lower benefitcost ratio because of higher investment cost and lower income from produce of the furrow and drip system while, the maximum gross benefit cost ratio i.e. 3.33 was observed in $75 \% \mathrm{RDF}$ through fertigation in equal splits at 7 days interval, due to low initial investment of the treatment and meanwhile higher income received from produce. Thus, drip fertigation system indicates the economic feasibility for higher productivity and sustainable okra production.

-KEY WORDS : Drip, Fertigation, RDF, Economic feasibility

- HOW TO CITE THIS PAPER : Jamrey, P.K. and Lakhawat, S.S. (2017). Economic feasibility of drip fertigation in okra. Internat. J. Agric. Engg., 10(2) : 516-520, DOI: 10.15740/HAS/IJAE/10.2/516520. 